\title{
Rare primary fumours of the hypothalamus in adults: clinical course and surgical treatment
}

\section{Rzadkie pierwotne guzy podwzgórza u osób dorostych: przebieg kliniczny i leczenie chirurgiczne}

\author{
Krzysztof Majchrzak', Grażyna Bierzyńska-Macyszyn², Barbara Bobek-Billewicz², Henryk Majchrzak', Piotr Ładziński' \\ 'Department of Neurosurgery in Sosnowiec, Medical University of Silesia in Katowice, Poland \\ 2 Section of Pathomorphology, Medical University of Silesia in Katowice, Poland \\ ${ }_{3}^{3}$ Radiodiagnostics Department, Comprehensive Cancer Centre, Maria Sklodowska-Curie, Memorial Institute Branch, Gliwice, Poland
}

Neurologia i Neurochirurgia Polska 2010; 44, 6: 546-553

\begin{abstract}
Background and purpose: The paper presents the operative technique and the results of treatment of adult patients with primary tumours of the hypothalamus, including rare ones. The aim of the study was to show the possibility of safe surgical treatment of rare tumours of the hypothalamus through a bifrontal basal interhemispheric trans-lamina terminalis approach.

Material and methods: Five patients with tumours of the hypothalamus were operated on in the Neurosurgical Clinic in Sosnowiec between 1990 and 2008. There were 2 patients with craniopharyngiomas located exclusively in the third ventricle, and single patients with gemistocytic astrocytoma, Langerhans cell histiocytosis $\mathrm{X}$ and hamartoma of the hypothalamus each. The patients were treated surgically with a bifrontal basal interhemispheric trans-lamina terminalis approach. In two cases, the neuronavigation system with the use of tractography (DTI) was used to determine the location of the lamina terminalis, the posterior surface of the optic chiasm and the optic tracts.

Results: All lesions were resected totally, except for partially resected hamartoma of the hypothalamus. The most common postoperative complication was diabetes insipidus, which was transient in two cases. A long-lasting follow-up of all the patients operated on did not reveal regrowth of the lesion.
\end{abstract}

\section{Streszczenie}

Wstęp i cel pracy: W artykule przedstawiono technikę chirurgiczną oraz wyniki leczenia operacyjnego dorosłych chorych z pierwotnymi, w niektórych przypadkach rzadkimi, guzami podwzgórza. Celem pracy jest pokazanie możliwości bezpiecznego leczenia chirurgicznego pierwotnych, rzadko spostrzeganych guzów podwzgórza przez blaszkę graniczną z dostępu dwuczołowo-podstawnego, międzypółkulowego.

Materiał i metody: W latach 1990-2008 w Klinice Neurochirurgii w Sosnowcu operowano 5 pacjentów z guzami zlokalizowanymi w przedniej części podwzgórza, w tym 2 pacjentów z czaszkogardlakiem ograniczonym tylko do komory III mózgu i po jednym pacjencie z gwiaździakiem tucznokomórkowym, histiocytozą X oraz odpryskowcem podwzgórza. Chorzy byli operowani z dostępu dwuczołowo-podstawnego, międzypółkulowego przez blaszkę graniczną. W 2 przypadkach zastosowano system neuronawigacji z wykorzystaniem traktografii (DTI), co umożliwiło zlokalizowanie blaszki granicznej, tylnej powierzchni skrzyżowania nerwów wzrokowych oraz obustronnie pasma wzrokowego.

Wyniki: Guz o charakterze odpryskowca podwzgórza usunięto częściowo, pozostałe guzy całkowicie. Najczęstszym powikłaniem obserwowanym po operacji guzów podwzgórza była moczówka prosta (w 2 przypadkach przemijająca).

Correspondence address: Krzysztof Majchrzak, plac Medyków 1, 41-200 Sosnowiec, Poland, phone +48 3236820 24, fax +48 323682550 ,

e-mail:majchrzak.mr@gmail.com

Received: 28.03.2010; accepted: 24.09.2010 
Conclusions: The bifrontal basal interhemispheric trans-lamina terminalis approach allows for radical resection of primary tumours of the hypothalamus while avoiding serious postoperative deficits. This approach enabled the preservation of the olfactory bulb and tract and prevented damage of the frontal lobes. The use of DTI helped to establish the location and borders of the lamina terminalis, to establish the posterior surface of the optic chiasm and the optic tracts, and to save the anterior and lateral wall of the hypothalamus.

Key words: primary hypothalamic tumours, clinical signs, surgical treatment, bifrontal basal interhemispheric translamina terminalis approach, DTI, outcome.

\section{Introduction}

Tumours of the hypothalamus are relatively rare, and half of the cases occur in childhood. The most common primary lesions of this area include gliomas (68.6\%), germinomas, and - less frequently - teratomas (altogether $22.9 \%$ ) [1]. The third ventricle is secondarily penetrated by craniopharyngiomas which compress the hypothalamus [2-5]. Only rarely do craniopharyngiomas develop exclusively in the third ventricle [6].

Primary tumours of the hypothalamus cause endocrinological and thermoregulation disorders, dysorexia and visual field defects. Sometimes they lead to non-communicating hydrocephalus, obstructing both foramina of Monro [1].

In this paper we present five patients with primary tumours of the hypothalamus who were treated surgically by means of the bifrontal basal interhemispheric trans-lamina terminalis approach.

The interhemispheric approach allowing access to lesions penetrating the third ventricle, the region around the septum pellucidum or lateral ventricles from the suprasellar region has been described previously by other authors $[2,7,8]$. Modifications to this approach which make it possible not to traumatize the frontal lobes, maintain olfactory tracts and expose the suprasellar region have already been described by several neurosurgeons, of whom Dehdashti and de Tribolet made a particularly thorough description in 2005 [4-6,9]. However, the majority of descriptions found in the literature of the approach and related to the surgical treatment of tumours of the hypothalamus have been confined to resections of craniopharyngiomas $[4-6,8,9]$.
Długotrwała obserwacja chorych nie wykazała wznowy procesu ekspansywnego.

Wnioski: Dostęp dwuczołowo-podstawny, międzypółkulowy przez blaszkę graniczną umożliwił radykalną resekcję pierwotnych guzów podwzgórza bez powodowania poważnych powikłań pooperacyjnych. Ułatwił także zachowanie opuszki i pasma węchowego oraz zapobiegł uszkodzeniu płatów czołowych w trakcie operacji. Dzięki wykorzystaniu neuronawigacji wraz z DTI łatwiej było ustalić granice blaszki granicznej i tylną powierzchnię skrzyżowania nerwów wzrokowych, położenie pasm wzrokowych oraz zaoszczędzić przednie i boczne części podwzgórza.

Słowa kluczowe: pierwotne guzy podwzgórza, objawy kliniczne, leczenie chirurgiczne, dostęp dwuczołowo-podstawny, międzypółkulowy przez blaszkę graniczną, DTI, wyniki leczenia.

Below, we present the operative technique we applied in the surgical treatment of tumours of the hypothalamus, the clinical course of the condition in brief, as well as a diagnosis for five adult patients with primary tumours of the hypothalamus who were treated in the Department of Neurosurgery in Sosnowiec.

\section{Material and methods}

\section{Operative technique}

The patient is placed in a supine position. The apex of the head is then lowered by $15^{\circ}$ to $20^{\circ}$ in relation to the horizontal body. A skin incision is made in a binauricular line, starting at $1 \mathrm{~cm}$ in front of the tragus and along the hair line. After raising the skin flap we dissect the pericranial flap, which is sandwiched between two sponges and kept moist with saline during the procedure. The bifrontal craniotomy should be performed as close to the roof of the orbit as possible. The bone flap is removed in one piece. The posterior wall of the deroofed frontal sinus is removed with a rongeur. The entire mucosa of the frontal sinus should be removed. The dura of the brain should be incised as close to the base of the anterior fossa as possible. The superior sagittal sinus is ligated and incised. The falx cerebri is incised lengthways. Then we dissect both olfactory tracts using the existing subarachnoid space. The olfactory bulbs are also dissected. Afterwards, we expose both optic nerves, the optic chiasm, both anterior cerebral arteries in their A1 and A2 sections, and the anterior communicating artery (ACoA). Above the optic chiasm we identify the lamina terminalis, which constitutes the anterior-infe- 
rior limitation of the third ventricle, extending from the anterior commissure to the posterior surface of the optic chiasm, and laterally bordering with the optic tract on the left and right side. It sometimes happens that access to the lamina terminalis is hindered by the $\mathrm{ACoA}$ complex. In such a case, we try to carefully dissect free this area and change the position of the ACoA. In autopsy studies, Italian authors did not find it necessary to mobilise the anterior cerebral artery-ACoA complex in order to achieve free access to the lamina terminalis [10]. That study, however, was carried out on a limited number of autopsy preparations. We point to the perforating arteries deviating from the $\mathrm{ACoA}$, particularly the relatively strong subcallosal artery which supplies the hypothalamus with blood [11]. During the surgery, one should remember that there are supraoptic nuclei and columns of the fornix laterally from the lamina terminalis in the anterior wall of the hypothalamus. Damage done to them leads to endocrinological and cognitive disorders.

In two patients, a tractography (DTI) study was used to determine the position of the optic nerves, the optic chiasm and both optic tracts. This procedure prevents possible damage to these autonomous formations while incising the lamina terminalis and during the dissection of the tumour from the hypothalamus. It also enables the determination of the borders of the chiasm during the resection of a lesion joined with the posterior surface of the optic chiasm.

The lamina terminalis is then incised. The bag of the tumour - as long as there is one - should be carefully separated from the surrounding cerebral tissue. Hypothalamic astrocytoma and hamartoma tumours often originate from one wall of the third ventricle and do not infiltrate the second one, which facilitates surgical resection. The gliosis between the tumour and active hypothalamic structure is present in craniopharyngiomas confined to the third ventricle, which enabled us to perform proper resection. Additional features that distinguish the tumour from a normal one include difference in colour (more white/yellow for the optic tracts and hypothalamus and more grey for the tumour) and the fact that the tumour is not infiltrative. Particular attention needs to be paid not to damage the arterial vessels encircling the tumour as they provide the blood supply to the healthy part of the diencephalon. While operating within the hypothalamus and the third ventricle, one should try to use bipolar coagulation as little as possible. It is much better to use warm physiological saline and wet cotton swabs. When the lesion is firmly accreted to the poste- rior surface of the optic chiasm, we try to separate sharply these two formations. Sometimes the lesion reaches as far as to the floor of the third ventricle. In this case, it is essential to remove the lesion very carefully, as any damage done to the hypothalamus, particularly to the mammillary bodies, may result in a cerebral coma or temporary consciousness disorders. After the removal of the tumour, we tightly close the dura mater so that the cerebrospinal fluid cannot leak out. The wall of the frontal sinus is covered with the periosteal flap.

\section{Results}

\section{Case 1}

A 45-year-old woman was admitted to the clinic because of a several-year-long history of transient disturbances of vision and gradual growth of a lesion in the hypothalamus, detected in the magnetic resonance imaging (MRI). Several weeks before admission, the patient noticed a slight weakness of the left limbs. The patient was treated surgically. The tumour was mainly confined to the right wall of the hypothalamus. The lesion was cream-coloured and of increased consistency. The borderline of the tumour was not clearly visible. Incidentally, other authors also found it difficult to establish a border between the lesion and the hypothalamus in the case of gliomas of the third ventricle $[1,12]$.

The lesion was resected radically, as shown in a follow-up MRI performed on the third postoperative day (Fig. 1).

The diabetes insipidus occurred as a postoperative complication. The patient was discharged from hospital two weeks after the surgery, in good condition, with a minor psychoorganic syndrome. A histopathological examination revealed gemistocytic astrocytoma.

During the entire 9-year-long follow-up the patient's condition has been good. The patient did not report headaches. The paresis of the left limbs and the disequilibrium subsided, as did the symptoms of diabetes insipidus.

\section{Case 2}

A 36-year-old man suffered from a generalised epileptic attack two months before admission. It was followed by a hemiparesis of the left limbs that receded a week later. A brain MRI study performed as a result of the seizure demonstrated a tumour within the hypo- 

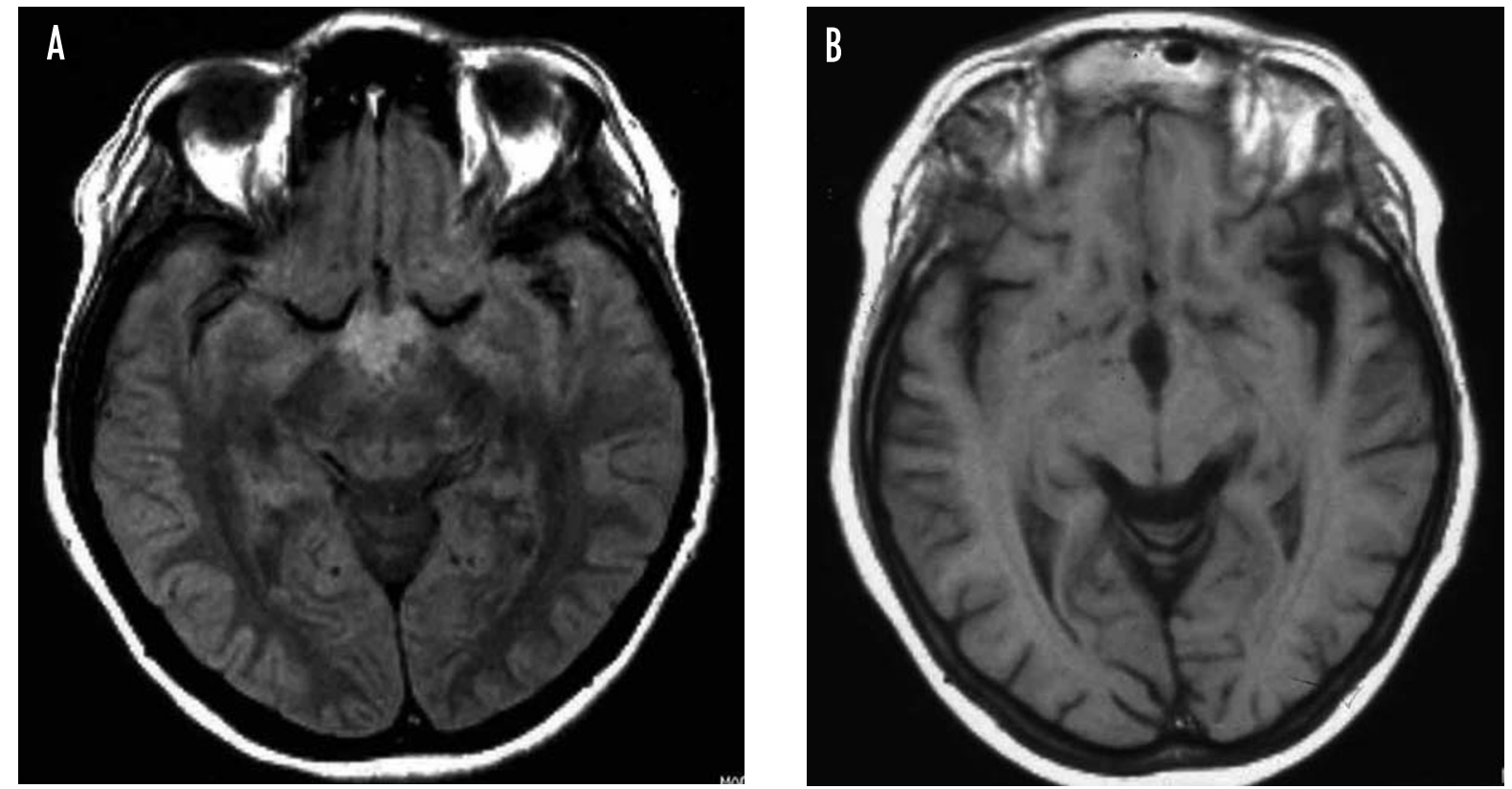

Fig. 1. MRI (axial plane) of patient with hypothalamic tumour, (A) before and (B) after surgery. Radical excision. Histopathological examination revealed gemistocytic astrocytoma
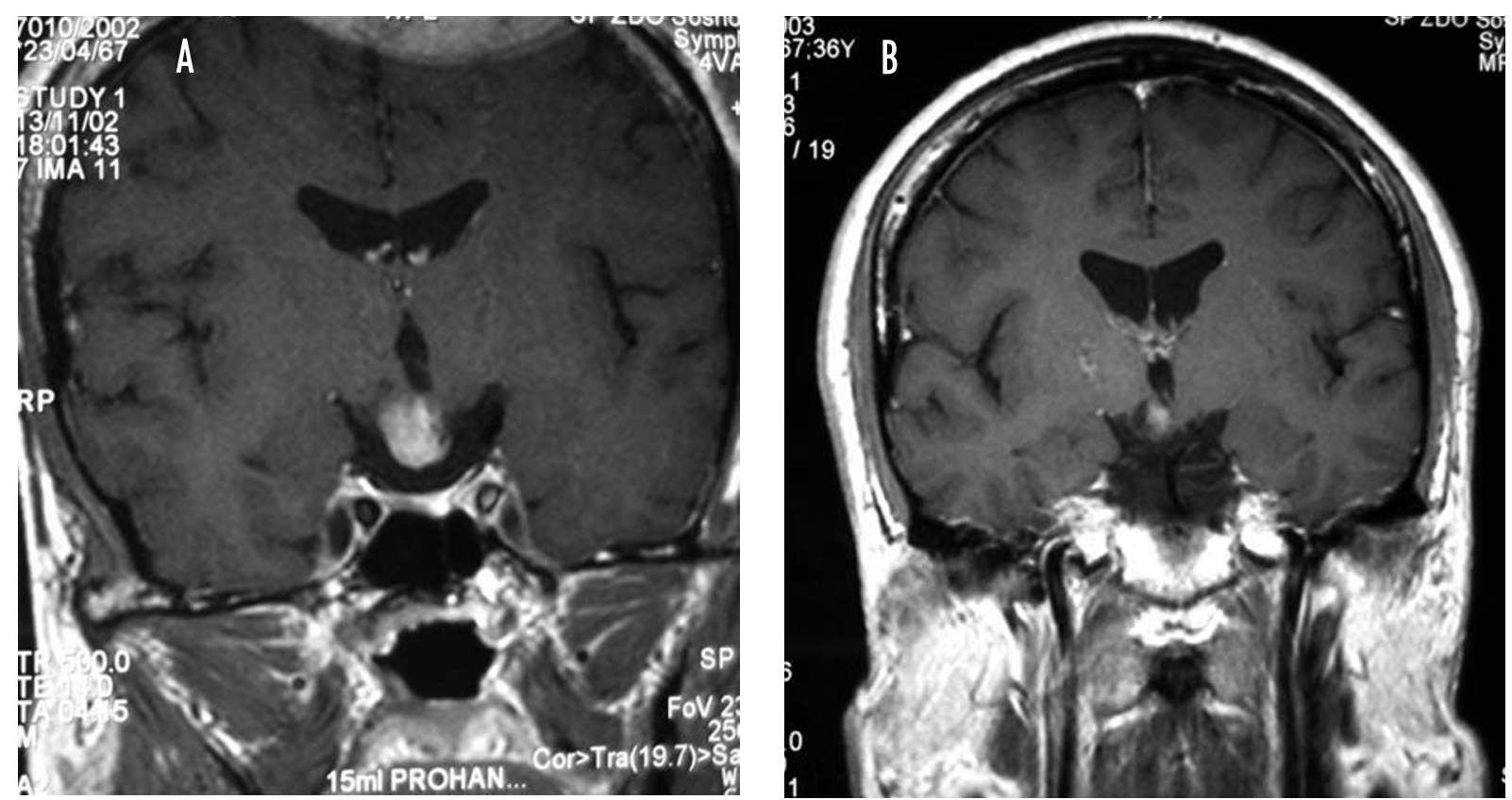

Fig. 2. MRI (frontal plane) of patient with hypothalamic tumour, (A) before and (B) affer surgery. Subtotal removal. Histopathological investigation revealed hamartoma of the hypothalamus

thalamus and near the optic chiasm. The expansive lesion enhanced slightly after contrast injection. The patient was operated on. The tumour was grey, bound with the anterior-abdominal part of the hypothalamus, and well separated from its environment. A control MRI study performed on the second postoperative day showed a subtotal resection (Fig. 2).

After the surgery, the symptoms of diabetes insipidus were observed. The postoperative course was complicated by the occurrence of a haematoma in the medial 

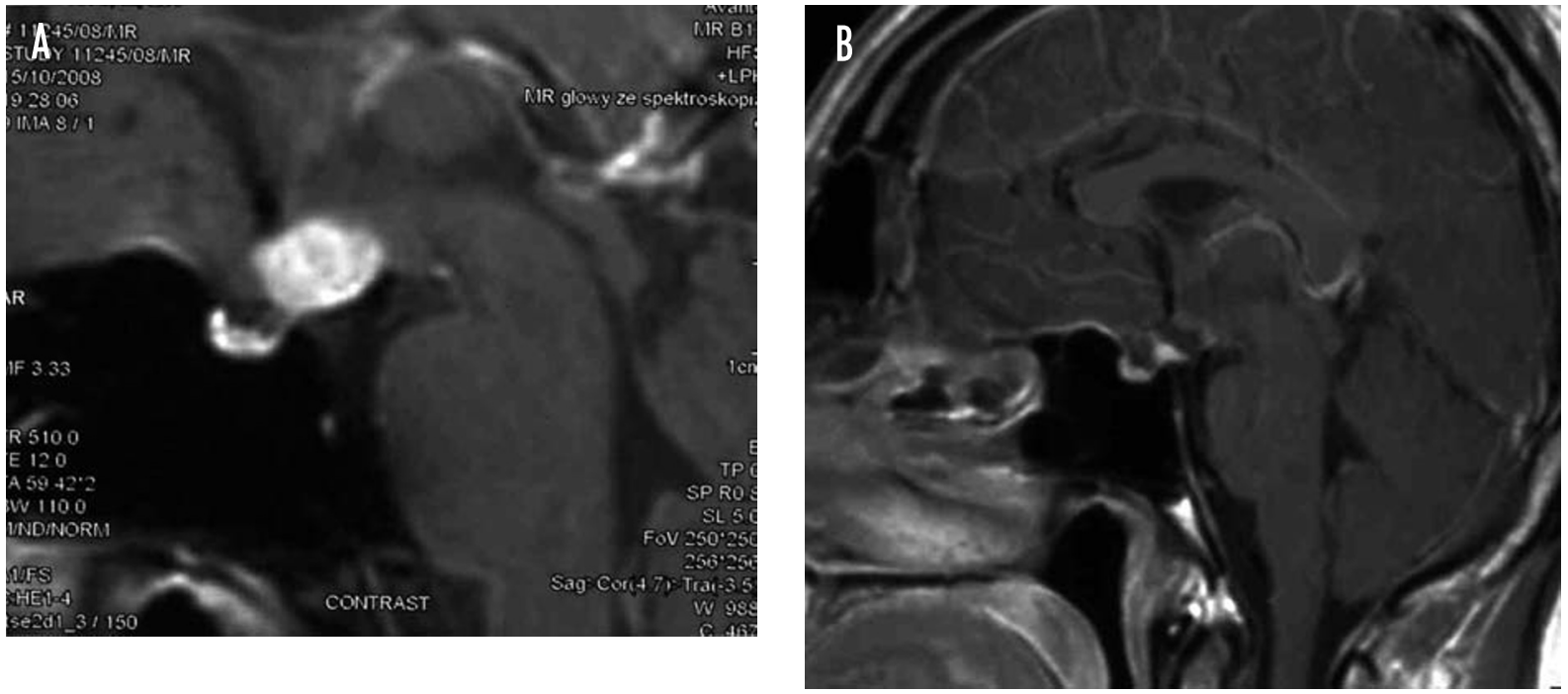

Fig. 3. MRI (sagittal plane) of patient with hypothalamic tumour, (A) before and (B) after surgery. Radical excision. Histopathological investigation revealed Langerhans cell histiocytosis $X$

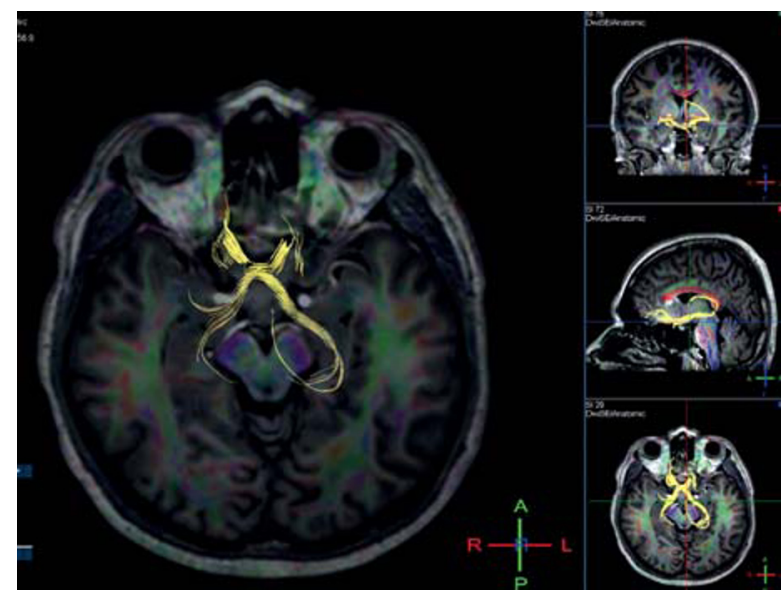

Fig. 4. DTI study (axial plane) before surgery. Lesion located posteriorly from optic chiasm, next to the optic tract. Visible fibres of beginning section of optic tract and optic chiasm

part of the right frontal lobe. The patient developed leftside paresis. Conservative therapy was applied. The paresis of the left limbs gradually receded. Three weeks after the operation the patient was discharged from hospital in a good condition. A histopathological examination revealed hamartoma of the hypothalamus.

The functional outcome of the patient, as assessed 8 years after the surgery, is good. Epileptic seizures were observed neither in the postoperative period nor in the years that followed. However, in neurological examination, slight paresis of the left limbs can be observed, which is mainly caused by a postoperative complication in the form of an intracerebral haematoma. The follow- up examinations showed no tumour regrowth, and the residual part of the lesion remains of the same size and does not enhance after contrast injection. The symptoms of diabetes insipidus are still present, and the dose of the applied medication has not been changed.

\section{Case 3}

A 29-year-old man complained of a 4-year history of excessive thirst and associated excessive diuresis. About six months prior to admission he noticed a decrease in libido and wasting hair on his face. On admission to the neurosurgery department he had an MRI performed which demonstrated a lesion in the anterior part of the hypothalamus that enhanced homogeneously after contrast injection. The lesion modelled the anteriorly adjacent optic chiasm and the first sections of the optic tract, which appeared thickened (Fig. 3).

A DTI study revealed fibres of the optic pathway on the left and right side (Fig. 4).

During the operation, the tumour turned out to be solid and quite hard, not bleeding, closely joined to the posterior surface of the optic chiasm but not infiltrating it. While separating the lesion from the area of the optic chiasm, the position of the chiasm was verified with a DTI study inserted for neuronavigation. An accretion of the lesion with the posterior surface of the optic chiasm in the case of another tumour - chordoid glioma - was observed by other authors. They reported a necessity to separate with great accuracy the lesion from the optic chiasm [13]. 
Radical excision of the neoplastic lesion was performed and was further confirmed in an MRI taken on the second postoperative day. A histopathological examination revealed Langerhans' cell histiocytosis X.

The postoperative course was uneventful. At present, one year after the surgery, the patient has resumed work as an IT specialist. He is being treated endocrinologically.

\section{Case 4}

A male patient, aged 32, had been complaining of increasing severe headaches for several months. He also reported dysmnesia and, intermittently, blurred field of vision. An MRI study revealed a solid lesion located in the third ventricle. The mass was almost homogeneously enhanced with gadolinium and there was no evidence of calcification or cystic regions (Fig. 5).

The patient was operated on. The neoplastic lesion was resected radically. The postoperative complications included diabetes insipidus, which receded after 3 months. A histopathological examination revealed craniopharyngioma. A six-year-long follow-up did not show a relapse of the neoplastic process.

\section{Case 5}

A 26-year-old man complained of headaches that had occurred six months earlier. His family also reported periods of disorientation. Moreover, recently he had become unusually irritable. An MRI showed a tumour of the third ventricle. The patient was treated surgically. Since the ACoA was running across the lamina terminalis, it was decided to bilaterally dissect free sections $\mathrm{A} 1$ and $\mathrm{A} 2$ of the anterior cerebral artery and retract the ACoA delicately upwards. This enabled a safe incision of the lamina terminalis. The lesion was partially liquid and partially solid, limited to the third ventricle. During resection of the solid part of the tumour, which was accreted to the anterior and lateral wall of the hypothalamus, we used DTI in the neuronavigation system. The postoperative course was complicated by diabetes insipidus which persisted for about two years of followup. Histopathological examination showed craniopharyngioma.

\section{Discussion}

The bifrontal interhemispheric trans-lamina terminalis approach which we used in the described cases enabled us to perform relatively non-destructive excisions of primary tumours of the hypothalamus. We succeeded in preserving the olfactory tracts and bulbs, and the compression of the frontal lobes was relatively small. We did not observe any negative effects of the superior sagittal sinus ligation. In none of the patients did infection occur as a consequence of opening the frontal sinuses. In the described craniotomy, the exposure of all anatomical formations was very good and enabled their maintenance. Other authors have reported the necessi-
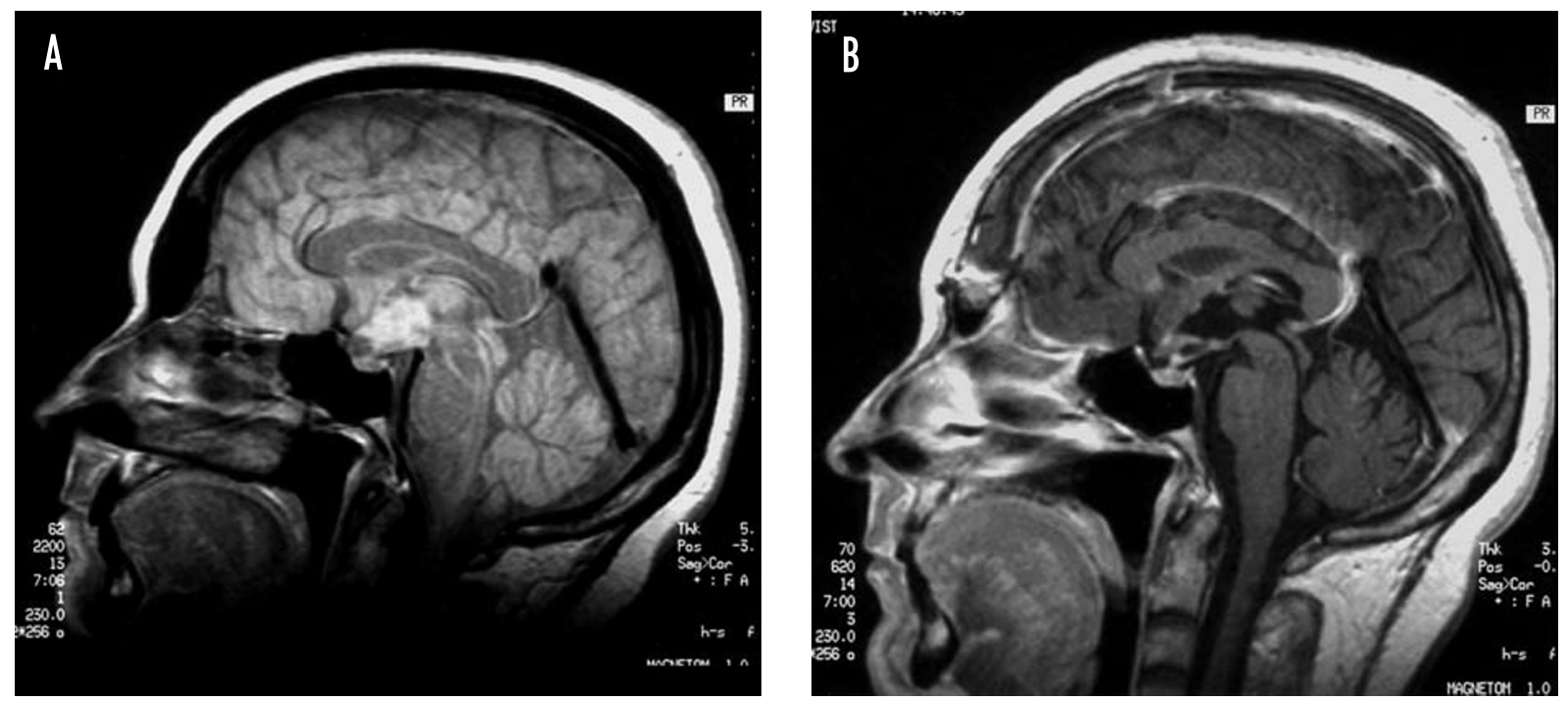

Fig. 5. MRI (A) before and (B) after surgery in patient with craniopharyngioma confined to the third ventricle. Radical excision 
ty to avoid as much as possible bipolar coagulation of the bleeding arteries while resecting suprasellar tumours penetrating the third ventricle $[9,14]$. In our operations, we used bipolar coagulation only exceptionally.

The question arises whether the applied operative technique - a rather extensive one - can challenge other less invasive methods.

Surgical treatment of tumours of this area by means of an endoscopic method has not become common yet, and it is considerably limited [13-17]. The approach to the lamina terminalis and the anterior part of the third ventricle has been verified on corpses in the circumstances of an anatomical laboratory [18].

Reports can be found in the literature about the possibility of a diagnostic biopsy of tumours of the hypothalamus by means of a rigid endoscope through a lateral ventricle, even in cases without hydrocephalus [17]. Among cases described by Souweidane, two were diagnosed with Langerhans cell histiocytosis X [17].

Lekovic reported on a possibility of endoscopic resection of a hypothalamic hamartoma in 2006 [16]. The author of the report completely resected the neoplastic lesion in one case, and in the other case the hamartoma was disconnected [16].

Cappabianca et al. [15] claimed that only patients with minor lesions indicative of hypothalamic hamartoma located in one wall of the hypothalamus and a space between the bottom of the hamartoma and pial surface of the interpeduncular cistern can be treated endoscopically [15]. After endoscopic surgery, some complications were observed, such as hemiparesis caused by damage to the internal capsule or the thalamus, and short-term memory disturbance. Considering the above, one can conclude that there are substantial limitations to this method of treatment, while the method of open surgery described in this paper poses no such limitations.

Our patient was middle-aged, which is rather uncommon for this type of tumour, occurring typically in younger patients [19-21]. During the surgery we noticed the sessile form of a lesion that was non-pedunculated and of a broad base, joined to the ventral part of the hypothalamus [22]. Convulsions are observed more frequently in the clinical course of this form of lesion [23]. Palmini presented a series of 13 patients treated surgically for convulsions caused by hamartoma of the hypothalamus [24]. In two patients, the epileptic seizures disappeared completely, and in the remaining 11 patients there was a $90 \%$ decrease in the frequency of seizures. In our patient, epileptic seizures disappeared despite only a partial resection of the lesion.
The patients - young men with craniopharyngioma - had tumours located exactly within the third ventricle. It was Maira [6] who mentioned a possibility of development of this kind of neoplastic lesion exclusively in the third ventricle. As in our patients, he found a solid tumour confined to the third ventricle without calcifications and a liquid part in all of the investigated patients [6].

Pathological lesions of this size which are entirely within the third ventricle can be easily operated on by means of an interhemispheric trans-lamina terminalis approach. The remote prognosis for patients treated surgically for primary tumours of the hypothalamus is favourable. The lesions were of limited character in our patients and we succeeded in separating them relatively well from the surrounding cerebral tissue.

\section{Conclusions}

1. The bifrontal basal interhemispheric trans-lamina terminalis approach allows for radical resection of primary tumours of the hypothalamus while avoiding serious postoperative deficits.

2. This approach enabled preservation of the olfactory bulb and tract and prevented damage of the frontal lobes.

3. The use of DTI helped to establish the location and borders of the lamina terminalis, to establish the posterior surface of the optic chiasm and optic tracts, and to save the anterior and lateral wall of the hypothalamus.

\section{Disclosure}

The authors report no conflict of interest.

\section{References}

1. Yasargil M.G. Microneurosurgery. IVB. Microneurosurgery of CNS tumors. Georg Thieme Verlag, Stuttgart 1996, p. 300.

2. Fahlbusch R., Honegger J., Paulus W., et al. Surgical treatment of craniopharyngiomas. Experience with 168 patients. $J$ Neurosurg 1999; 90: 237-250.

3. Samii M., Tatagiba M. Craniopharyngioma. In: Kaye A.H., Laws E.R. [eds.]. Brain tumors. Churchill Livingstone, London 2001, p. 945.

4. Shibuya M., Takayashu M., Suzuki Y., et al. Bifrontal basal interhemispheric approach to craniopharyngioma resection with or without division of the anterior communicating artery. $J$ Neurosurg 1996; 84: 951-956.

5. Shirane R., Su C.C., Kusakka Y., et al. Surgical outcomes in 31 patients with craniopharyngiomas extending outside the 
suprasellar cistern: an evaluation of the frontobasal interhemispheric approach. J Neurosurg 2002; 96: 704-712.

6. Maira G., Anile C., Colosimo C., et al. Craniopharyngiomas of the third ventricle: trans-lamina terminalis approach. Neurosurgery 2000; 47: 857-865.

7. Oi S., Samii A., Samii M. Operative techniques for tumors in the third ventricle. Oper Tech Neurosurg 2003; 6: 205-214.

8. Suzuki J., Katakura R., Mori T. Interhemispheric approach through the lamina terminalis to tumors of the anterior part of the third ventricle. Surg Neurol 1984; 22: 157-163.

9. Dehdashti A.R., de Tribolet N. Frontobasal interhemispheric trans-lamina terminalis approach for suprasellar lesions. Oper Neurosurg 2005; 2: 418-424.

10. de Divitis O., Angileri F.F., d'Avella D., et al. Microsurgical anatomic features of the lamina terminalis. Neurosurgery 2002; 50: 563-569.

11. Serizawa T., Saeki N., Yamaura A. Microsurgical anatomy and clinical significance of the anterior communicating artery and its perforating branches. Neurosurgery 1997; 40: 1211-1216.

12. Albright A.L. Hypothalamic hamartomas. In: Berger M.S., Prados M.D. [eds.]. Textbook of neuro-oncology. Elsevier Saunders, Philadelphia 2005, p. 652.

13. Carrasco R., Pascual J.M., Reina T., et al. Chordoid glioma of the third ventricle attached to the optic chiasm. Successful removal through a trans-lamina terminalis approach. Clin Neurol Neurosurg 2008; 110: 828-833.

14. Page R.B. Dieencephalic structures at risk in third ventricular surgery. In: Apuzzo M.L.J. [ed.]. Surgery of third ventricle. Williams \& Wilkins, Baltimore 1987, p. 553.

15. Cappabianca P., Cinalli G., Gangemi M., et al. Application of neuroendoscopy to intraventricular lesions. Neurosurg Suppl 2008; 62: 575-598.

16. Lekovic G.P., Gonzalez L.F., Erfan Feiz I., et al. Endoscopic resection of hypothalamic hamartoma using a novel variable aspiration tissue retractor. Neurosurgery 2006; 58 (1 Suppl): 166-169.

17. Souweidane M.M. Endoscopic surgery for intraventricular brain tumors in patients without hydrocephalus. Neurosurgery 2005; 57: $312-318$

18. Abdou M.S., Cohen A.R. Endoscopic surgery of the third ventricle: the subfrontal trans-lamina terminalis approach. Minim Invasive Neurosurg 2000; 43: 208-211.

19. Mossakowski M.J., Liberski P.P. Guzy układu nerwowego. Zaktad Narodowy im. Ossolińskich, Wydarwnictwo Polskiej Akademii Nauk, Wrocław 1997.

20. Arita K., Koji I., Kurisu K. Subsidence of seizures by stereotactic radiation in a patient with hypothalamic hamartoma. $J$ Neurosurg 1998; 89: 645-648.

21. Chen T.C., Gonzales-Gomez I., Mc Comb J. Uncommon glial tumors. In: Kaye A.H., Laws E.R. Brain tumors. Churchill Livingstone, London 2001, p. 563.

22. Yamada S., Sano T. Neuropathology of the hypothalamus. In: Barrow D.L., Selman W. [eds.]. Neuroendocrinology. Williams \& Wilkins, Baltimore 1998, p. 259.

23. Boyko O.B., Curnes J.T., Oakes W.J., et al. Hamartoma of the tuber cinereum: CT, MR and pathologic findings. Am J Neuroradiol 1991; 12: 309-314.
24. Palmini A., Handler C., Andemrann E., et al. Resection of the lesion in patients with hypothalamic hamartoma and catastrophic epilepsy. Neurology 2002; 58: 1338-1347. 